\title{
Exploring the bushmeat market in Brussels, Belgium: a clandestine luxury business
}

\author{
Sophie Gombeer ${ }^{1}$ (D) Casimir Nebesse ${ }^{2}$ - Prescott Musaba ${ }^{2}$ - Steve Ngoy $^{2}$. \\ Marc Peeters $^{3} \cdot$ Ann Vanderheyden $^{1} \cdot$ Kenny Meganck ${ }^{4} \cdot$ Nathalie Smitz $^{4}$. \\ Frank Geers $^{5}$ - Sarah Van Den Heuvel ${ }^{6}$. Thierry Backeljau ${ }^{1,7} \cdot$ Marc De Meyer $^{4}$. \\ Erik Verheyen ${ }^{7,8}$
}

Received: 15 April 2020/Revised: 10 September 2020/Accepted: 31 October 2020 /

Published online: 10 November 2020

(C) The Author(s) 2020

\begin{abstract}
The European Union prohibits the import of meat (products) unless specifically authorised and certified as being eligible for import. Nevertheless, various scientific papers report that passengers from west and central African countries illegally import large quantities of meat, including bushmeat, into Europe via its international airports. They also suggest that African bushmeat is an organised luxury market in Europe. In the present study we explore several aspects of the African bushmeat market in Brussels, Belgium. We demonstrate the clandestine nature of this market where bushmeat is sold at prices at the top of the range of premium livestock and game meat. Inquiries among central and western African expatriates living in Belgium, who frequently travel to their home countries, indicate that the consumption of bushmeat is culturally driven by the desire to remain connected to their countries of origin. DNA-based identifications of 15 bushmeat pieces bought in Brussels, reveal that various mammal species, including CITES-listed species, are being sold. Moreover, we find that several of these bushmeat pieces were mislabelled.
\end{abstract}

Keywords Bushmeat - DNA-based identification - CITES - Illegal trade · African expatriates

Communicated by Dirk Sven Schmeller.

This article belongs to the Topical Collection: Biodiversity exploitation and use.

Electronic supplementary material The online version of this article (https://doi.org/10.1007/s10531-02002074-7) contains supplementary material, which is available to authorized users.

Sophie Gombeer

sophie.gombeer@naturalsciences.be

Extended author information available on the last page of the article 


\section{Introduction}

Wild meat, the meat derived from non-domesticated terrestrial animals hunted for consumption or sale as food, ensures the food supply in many regions of the world. In the African tropical rain forest regions, wild meat is referred to as bushmeat. Especially in regions where meat from domesticated animals is scarce or expensive, it often represents the primary or only source of animal protein (Swamy and Pinedo-Vasquez 2014; Wilkie et al. 2016). In such areas, the bushmeat trade also generates income by providing cash through trade (Nasi et al. 2008; Brown and Marks 2008). Hunting and the consumption of bushmeat are integral parts of the cultural heritage of many African communities and extend to the expatriate urban elite who consider it a delicacy and a way to maintain links with a traditional lifestyle (Cawthorn and Hoffman 2015; Ichikawa et al. 2016). This taste preference and desire to retain cultural ties has generated an international market for bushmeat, with widespread organised trade networks feeding this international demand (Chaber et al. 2010).

International bushmeat trade is illegal. The European Union bans the import of meat (products) by passengers, unless it meets the certification requirements for commercial consignments and is presented at the EU border control post with the correct documentation (EU 2019/2122; European Commission 2019). Many wildlife species that are frequently consumed and traded as bushmeat may carry pathogens, and the hunting and processing of bushmeat has been linked to several disease outbreaks (Kurpiers et al. 2016; Dawson 2018; Katani et al. 2019). As such, the uncontrolled import of bushmeat may represent health risks on human and animal populations in the countries of destination.

There is no reliable information on the scale of the international bushmeat trade, yet growing evidence suggests that the amount of bushmeat imported in Europe is substantial (Chaber et al. 2010; Falk et al. 2013). During a survey at Roissy-Charles de Gaulle airport (Paris, France) seven percent of the inspected passengers from west and central African countries were carrying bushmeat, while $25 \%$ had livestock meat in their luggage (Chaber et al. 2010). Yet, bushmeat consignments were over $20 \mathrm{~kg}$ on average (up to $51 \mathrm{~kg}$ ), compared to $4 \mathrm{~kg}$ for livestock. This and other studies indicate that bushmeat is not only imported for personal use, but also to supply an illegal market for African bushmeat in Europe (Chaber et al. 2010; Falk et al. 2013; Dawson 2018). News reports on the illegal sale of bushmeat in European cities (Milius 2005; Brown 2006; Marris 2006; Oger 2011) describe the clandestine character of these markets and note that customers are prepared to pay high prices to purchase bushmeat.

The illegal international bushmeat trade contributes to the overexploitation of vulnerable and protected species. Studies at European airports for example reported the illegal import of species that are listed as Vulnerable or Critically Endangered by the International Union for Conservation of Nature (IUCN) and that are protected under the Convention on International Trade in Endangered Species of Wild Fauna and Flora (CITES) (Chaber et al. 2010; Falk et al. 2013; Wood et al. 2014).

The current study provides the very first data on the clandestine bushmeat market in Brussels, Belgium (including communities recognised under the Brussels Capital Region). We check the CITES and IUCN Red List status of the species sold as bushmeat and their market prices. In addition, we examine the motivations for this trade by means of focus group discussions with expatriates from central and western African countries. Because carcasses are usually smoked or cut into small pieces, morphological identification of bushmeat pieces is often unreliable. Therefore, we use DNA barcoding of the 
mitochondrial markers cytochrome $b$ (cytb) and cytochrome $c$ oxidase subunit 1 (COI) to identify the bushmeat samples (D'Amato et al. 2013; Gaubert et al. 2015).

\section{Materials and methods}

\section{Sample collection}

In November and December 2017, we attempted to purchase bushmeat at nine African grocery stores in the "Matongé" quarter in Brussels. The shops were selected because (fresh) African food products were on display (e.g. palm kernel oil, cooking ingredients), and the shopkeepers were of African descent and speaking Swahili or Lingala. In three shops bushmeat was for sale, so that over the course of 2 months we bought twelve bushmeat pieces. In May 2018 three additional bushmeat samples were bought in two other African grocery stores in "Matongé" by journalists of the Belgian public television stations RTBF (www.rtbf.be) and VRT (www.vrt.be).

\section{DNA-based bushmeat species identification}

Bushmeat tissue pieces were taken $0.5-1 \mathrm{~cm}$ under the surface and genomic DNA was extracted using the Qiagen QIAamp ${ }^{\circledR}$ DNA Micro kit following the manufacturer's instructions. A $658 \mathrm{bp}$ long COI fragment was amplified using the LCO1490 and HCO2198 primer pair (Folmer et al. 1994), while the primer L14723 or L14724NAT was combined with H15915 to amplify a 1140 bp fragment of cytb (Ducroz et al. 2001; Guicking et al. 2006). Details on PCR and sequencing conditions can be found in the supplementary material (Online Resource ESM_1).

To identify the bushmeat pieces the generated sequences were compared against the GenBank nucleotide collection (nr/nt) database using BLASTN (www.blast.ncbi.nlm.nih. gov/Blast.cgi) and against the Species Level Barcode Records using the BOLD Identification System (www.boldsystems.org). Neighbour-Joining trees were constructed to complement the interpretation of the results from the search engines (see Online Resource ESM_1 for more details).

\section{Focus group discussions}

We organised qualitative group discussions to gain insight into the reasons for bushmeat import and consumption within the framework of a large awareness project implemented by Brussels Airport aimed at sensitizing African travellers about import rules and policies. Participants were selected from a panel of volunteers who had signed up to take part in market research on a wide range of topics. They included expatriates from central and western African countries, who frequently return to the country where they, or their ancestors, were born. Sixteen persons engaged in the discussions (Table 1). The participants originated from seven countries (Angola, Burundi, Cameroon, the Democratic Republic of the Congo, the Republic of Guinea, Senegal, Togo) and most have been living in Belgium for at least 10 years. The discussions were organised in two separate groups of eight participants, and lasted for approximately $2 \mathrm{~h}$.

In order to safeguard the authenticity of the answers, participants entered the group discussions without prior knowledge of the subject. No reference to the importation of food items or bushmeat was made during the recruitment of the participants, nor during the 
Table 1 Personal information for the travelling expatriates that participated in the focus group discussions

\begin{tabular}{|c|c|c|c|c|c|c|c|}
\hline $\begin{array}{l}\text { Focus } \\
\text { group }\end{array}$ & Gender & Age & $\begin{array}{l}\text { Country of } \\
\text { origin }\end{array}$ & $\begin{array}{l}\text { Years in } \\
\text { Belgium* }\end{array}$ & $\begin{array}{l}\text { Frequency of } \\
\text { travel to sub- } \\
\text { Saharan Africa }\end{array}$ & $\begin{array}{l}\text { Professional } \\
\text { activities }\end{array}$ & $\begin{array}{l}\text { Family members } \\
\text { in Belgium }\end{array}$ \\
\hline 1 & Female & 29 & Burundi & 15 & $\begin{array}{l}\text { Once every } \\
\text { year }\end{array}$ & Social assistant & $\begin{array}{l}\text { Partner, mother, } \\
\text { brother, uncle, } \\
\text { cousins }\end{array}$ \\
\hline 1 & Male & 45 & $\begin{array}{l}\text { Democratic } \\
\text { Republic } \\
\text { of the } \\
\text { Congo }\end{array}$ & 26 & $\begin{array}{l}\text { Once every } \\
2 \text { years }\end{array}$ & Independent & Partner, children \\
\hline 1 & Male & 24 & Angola & 6 & $\begin{array}{l}\text { Once every } \\
\text { year or once } \\
\text { every } 2 \text { years }\end{array}$ & Student & Parents, brother \\
\hline 1 & Female & 50 & $\begin{array}{l}\text { Democratic } \\
\text { Republic } \\
\text { of the } \\
\text { Congo }\end{array}$ & 30 & $\begin{array}{l}\text { Once every } \\
2 \text { years }\end{array}$ & Caregiver & Partner, children \\
\hline 1 & Female & 50 & Senegal & 49 & $\begin{array}{l}\text { Once every } \\
2 \text { years }\end{array}$ & $\begin{array}{l}\text { Government } \\
\text { employee }\end{array}$ & $\begin{array}{l}\text { (Grand)parents, } \\
\text { brother, sister, } \\
\text { extended } \\
\text { family }\end{array}$ \\
\hline 1 & Male & 27 & $\begin{array}{l}\text { Republic of } \\
\text { Guinea }\end{array}$ & 3 & $\begin{array}{l}\text { Twice every } \\
\text { year }\end{array}$ & Student & None \\
\hline 1 & Male & 35 & Burundi & 35 & $\begin{array}{l}\text { Once every } \\
\text { year }\end{array}$ & $\begin{array}{l}\text { Seeking } \\
\text { employment }\end{array}$ & Half of family \\
\hline 1 & Male & 39 & Cameroon & 4 & $\begin{array}{l}\text { Once every } \\
\text { year }\end{array}$ & $\begin{array}{l}\text { Researcher and } \\
\text { student }\end{array}$ & Partner, child \\
\hline 2 & Female & 37 & Cameroon & 15 & $\begin{array}{c}\text { Once every } \\
2 \text { years }\end{array}$ & $\begin{array}{c}\text { Childcare } \\
\text { worker }\end{array}$ & Partner, children \\
\hline 2 & Female & 40 & Senegal & 14 & $\begin{array}{l}\text { Once every } \\
\text { year }\end{array}$ & Tax lawyer & Partner \\
\hline 2 & Female & 35 & $\begin{array}{l}\text { Democratic } \\
\text { Republic } \\
\text { of the } \\
\text { Congo }\end{array}$ & 34 & $\begin{array}{l}\text { Once every } \\
\text { year }\end{array}$ & $\begin{array}{l}\text { Administrative } \\
\text { employee }\end{array}$ & $\begin{array}{l}\text { Partner, child, } \\
\text { parents, } \\
\text { extended } \\
\text { family }\end{array}$ \\
\hline 2 & Male & 39 & Togo & 18 & $\begin{array}{c}\text { Once every } \\
2 \text { years }\end{array}$ & Engineer & Child \\
\hline 2 & Male & 39 & $\begin{array}{l}\text { Democratic } \\
\text { Republic } \\
\text { of the } \\
\text { Congo }\end{array}$ & 12 & $\begin{array}{l}\text { Once every } \\
\text { year }\end{array}$ & $\begin{array}{l}\text { Administrative } \\
\text { employee }\end{array}$ & None \\
\hline 2 & Female & 20 & $\begin{array}{l}\text { Democratic } \\
\text { Republic } \\
\text { of the } \\
\text { Congo }\end{array}$ & 20 & $\begin{array}{l}\text { Three times at } \\
\text { ages } 1,11 \& \\
20\end{array}$ & $\begin{array}{l}\text { Student and } \\
\text { receptionist }\end{array}$ & Extended family \\
\hline 2 & Female & 28 & Cameroon & 10 & $\begin{array}{c}\text { Minimal once } \\
\text { every year }\end{array}$ & $\begin{array}{r}\text { Financial } \\
\text { auditor }\end{array}$ & Aunts, uncles \\
\hline 2 & Male & 41 & $\begin{array}{l}\text { Democratic } \\
\text { Republic } \\
\text { of the } \\
\text { Congo }\end{array}$ & 15 & $\begin{array}{l}\text { Once every } \\
\text { year }\end{array}$ & Civil engineer & $\begin{array}{l}\text { Partner, children, } \\
\text { brother }\end{array}$ \\
\hline
\end{tabular}

*At the time the group discussions were conducted in December 2017 
introduction at the beginning of the group discussions. The facilitator was an experienced ( $>20$ years) market researcher with a psychology background. The discussions were held using an impartial approach, without directing the answers or judging the participants. The facilitator started by creating a relaxed environment before beginning the discussions using a pre-set procedure and predefined questions (Online Resource ESM_2). At first, the discussions focussed on the personal context concerning motivation and importance of travelling to the country of origin after which they slowly moved towards the subject of importing food items, plants, other goods and eventually also bushmeat.

\section{Results}

\section{Sample collection}

Bushmeat was not on display in the African grocery stores visited. After specifically inquiring after its availability, six vendors declared they did not sell bushmeat. These vendors said that selling bushmeat is illegal and that they did not want to be fined. Conversely, in five shops the vendors did concede after negotiation that they had bushmeat for sale. The meat was either kept in the back of the store or it could be picked up the following day. Three vendors provided a phone number which allowed us to check when a new shipment of bushmeat was expected to arrive, which occurred with an average interval of 1-2 weeks. All bushmeat was claimed by the vendors to originate from the Democratic Republic of the Congo and sold under vernacular (French, Lingala, Swahili) species names (Table 2). All pieces were heavily smoked and most were wrapped in non-transparent plastic. The announced price of the bushmeat was $40 € / \mathrm{kg}$. However, the pieces were not weighed, except for the three lightest and two heaviest ones (Table 2). So, after taking into account the weight of the individual pieces, prices ranged from $31-62 € / \mathrm{kg}$.

\section{DNA-based bushmeat species identification}

The 15 bushmeat samples were successfully sequenced for both DNA fragments (only cyt $b$ for sample VRT002) and the sequences were deposited in GenBank (COI: MT020839-MT020852; cytb: MT024303-MT024317). Yet, seven of the 15 bushmeat pieces could not be identified to the species-level with certainty (Table 2, Online Resources ESM_1 and ESM_3). For eight pieces_-including the three monkey samples- the DNAbased identification did not correspond to the vernacular name communicated by the vendors. Two pieces sold as African buffalo were cattle, while in three instances (Table 2: samples RTBF001, BXL003, BXL007) the identified species belonged to a different family than the alleged species reported by the vendors. The remaining three misidentifications were inaccurate at the genus level.

Four pieces of bushmeat originated from three CITES-listed species: red-tailed monkey (Cercopithecus ascanius, sample RTBF001), De Brazza's monkey (C. neglectus, samples BXL011 and VRT001) and blue duiker (Philantomba monticola, sample VRT002). Two other pieces of bushmeat (BXL004 and BXL008) originated from "duiker", without further distinction between Peters' duiker (Cephalophus callipygus), Ogilby's duiker $(C$. ogilbyi) and Weyns's duiker (C. weynsi). Of these three species only Ogilby's duiker is listed on Appendix II of CITES. 


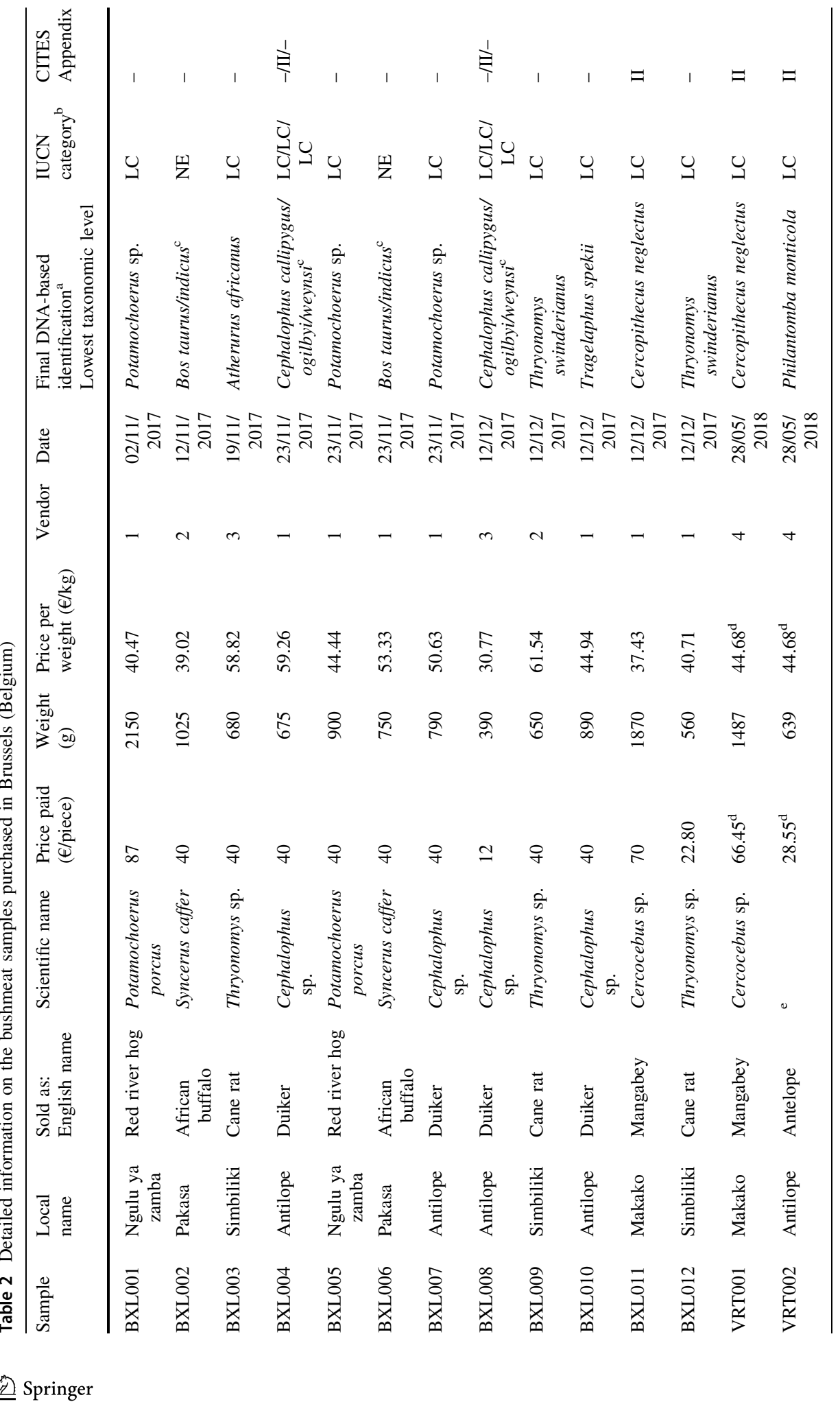




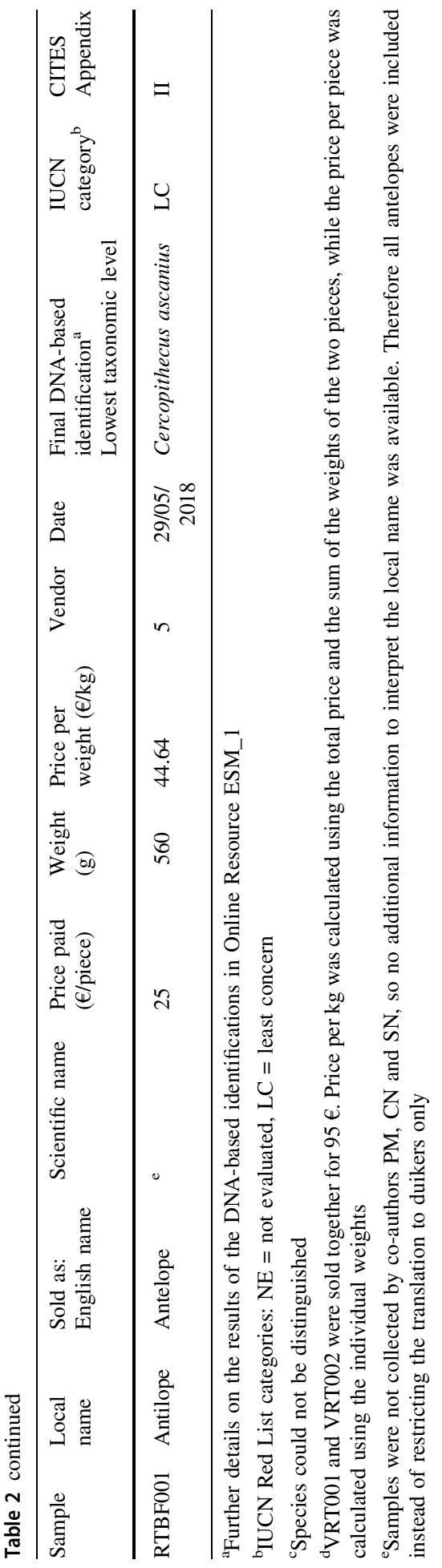




\section{Focus group discussions}

All focus group participants, emphasised the importance of staying connected with the country where they, or their ancestors, were born as well as with the local customs, habits and rituals. They expressed a profound sense of attachment to their relatives and to their ancestral region. In general, all participants perceived African food items as tastier than European products, as well as purer and of better quality. Fifteen participants declared they often import African food items, including bushmeat, into Belgium for personal use, to introduce children to the taste of African food, and to share with relatives and close friends. Several participants benefitted financially from importing these goods, and for some this activity generated enough revenue to pay their travel expenses.

All participants were aware of the existence of import regulations on food items and understood why the import of certain goods is illegal, e.g. to prevent disease or protect endangered species, yet they all believed that the items they import are safe. All participants indicated that there is confusion on what is allowed (and what not) and why certain food items are forbidden. Small quantities of dried food, well-packed or transported in cooler boxes, are considered safe and the sale of cooler boxes at African airports is perceived as an affirmation that transporting all food items is allowed. In addition, custom controls are experienced by the participants as a lottery, "sometimes it passes, sometimes it doesn't".

\section{Discussion}

\section{Availability of bushmeat and drivers of the market in Brussels}

All vendors at the African grocery stores visited in Brussels appeared to be aware that importing and selling bushmeat is illegal. Those who were not deterred from selling bushmeat by the prospect of getting fined, kept the meat hidden. The clandestine, under the counter selling of bushmeat outside Africa has also been observed in London and Paris (Brown 2006; Oger 2011). Our sampling strategy did not allow to estimate the amount of bushmeat that was in stock at the different shops, yet the fact that new shipments arrived on a regular basis indicate that bushmeat is commonly available. The financial benefits from importing food stuff mentioned by some of the focus group participants, adds to the suspicion that the bushmeat market in Brussels is thriving well, the more so as some vendors declared to have stores and customers in other Belgian cities.

The culture-based motivation for the consumption of bushmeat by African expatriates in Brussels, i.e. to retain family and cultural ties, and to share the bushmeat with friends and relatives, has been reported elsewhere, too (Bair-Brake et al. 2014; Walz et al. 2017). The participants understood the import ban for certain products (disease risks or protected species), but were under the impression that some imports are permitted. The confusion about import regulations also arose during focus group discussions in the USA (Bair-Brake et al. 2014; Walz et al. 2017) and Germany (Jansen et al. 2016). This may be the consequence of the fact that information on import regulations is derived from word to mouth information, and personal experience or experiences from family and friends. There appears to be no incentive to actively search for correct official information.

Since bushmeat is illegal in Europe, there are no rules or control with respect to its identification and labelling. Instead, species identifications entirely rely on the doubtful information provided by the vendors. So, not unexpectedly, our limited data suggest that 
the bushmeat sold in Brussels is frequently mislabelled. This is in line with the equally high level of misidentifications of bushmeat reported on African markets (Bitanyi et al. 2011; Minhós et al. 2013; Galimberti et al. 2015). The fact that bushmeat is often sold under erroneous species names may be explained by the informal character of its commodity chain (Bitanyi et al. 2011; Boratto and Gore 2018). Hence, pieces of bushmeat may pass through several hands so that eventual species information is easily lost along the way. Moreover, the (semi)processed state of the bushmeat probably makes it difficult for vendors to know exactly what they are selling.

In some cases, however, mislabelling may be deliberate. Studies on African markets have shown that hunters and sellers may lie about the identity of the species concerned when it is, for example, a protected species or in order to meet customer expectations (Lindsey et al. 2011; Bitanyi et al. 2011; Minhós et al. 2013). The antelope that turned out to be a monkey (Table 2: sample RTBF001) may be an example where the vendor deceived the customer, since the sample involved a hand and was thus easily recognisable as part of a primate by the vendor. This specific purchase concerned an ahead-order of antelope which was collected the next day, at which time the piece was wrapped in non-transparent plastic and thus unavailable for visual inspection. The two pieces that were sold as African buffalo but that in fact were cattle are another example of deliberate mislabelling of livestock meat as bushmeat.

\section{Bushmeat and species conservation}

We were unable to identify all bushmeat pieces to the species level because the DNA reference databases are not complete and/or because the taxonomy of certain species is not yet fully resolved. This affected the number of CITES-listed species, since of the three potential duiker species identified for samples BXL004 and BXL008 only Ogilby's duiker (Cephalophus ogilbyi) is currently listed on Appendix II. Taking this into account, four up to six of the 15 obtained meat pieces originated from protected species, a proportion comparable to the approximate $1 / 3$ of carcasses identified as CITES-listed species at Paris (France) and Swiss airports (Chaber et al. 2010; Wood et al. 2014).

Studies on the international bushmeat trade also found several species listed as Vulnerable, Endangered or Critically Endangered on the IUCN Red List (Chaber et al. 2010; Smith et al. 2012; Wood et al. 2014). In contrast, all of the wild African species identified in the current study are listed as Least Concern. However, this does not mean that these species are not at risk to become threatened in the (near) future. For instance, primates include the highest number of species threatened primarily by human hunt (Ripple et al. 2016). They constitute an important portion of the international bushmeat trade (Brown 2006; Chaber et al. 2010; Smith et al. 2012) and accounted for 3/15 of the pieces bought in the current study. Duikers (Cephalophinae) also represent a large proportion of the bushmeat trade in Africa (Fa and Brown 2009; Olayemi et al. 2011) and make up an important share of seizures at European airports (Chaber et al. 2010; Wood et al. 2014). Especially for these taxa accurate information on the quantity and identity of traded meat might be important to better assess the impact of the (international) bushmeat trade on the population size trends of individual species. 


\section{Luxury status of bushmeat in Brussels}

Information on the price of imported bushmeat is scarce, yet reports on illegal markets in west European cities indicate that bushmeat is more expensive than livestock meat (Brown 2006; Marris 2006). Interviews with three bushmeat vendors in Paris, trading by telephone or on the streets, indicated they charge 20-30 $€ / \mathrm{kg}$ (Chaber et al. 2010), prices higher compared to an average of $15 € / \mathrm{kg}$ for domestic meat sold in French supermarkets at the time. Since the interviews were conducted in 2008, the price for bushmeat in Paris may have risen and might now be comparable to the $40 € / \mathrm{kg}$ declared by vendors in 2017-2018 in Brussels. This latter price, however, was most often applied as a price per piece instead of price per weight, a custom comparable to the practice at African markets (Brown and Marks 2008; Okiwelu et al. 2009; Minhós et al. 2013). Due to this practice, prices for bushmeat in the current study were almost always (much) higher than the announced $40 € /$ $\mathrm{kg}$. Therefore, a comparison of the prices announced in Paris with the prices paid in the current study might not be straightforward without information on the actual prices per kilogram charged in Paris.

While the price for bushmeat in Brussels reaches up to $62 € / \mathrm{kg}$ there seems to be no relationship between the price and the species involved (irrespective of who provided the species identification). Consulting the price of meat on the web shops of the three largest supermarket chains in Belgium (October 2019), only game meat (i.e. roe-deer, red deer and partridge) was sold at prices above $50 € / \mathrm{kg}$, while premium beef reached prices of $40-45 € /$ $\mathrm{kg}$. This comparison supports the luxury status of bushmeat in Brussels.

Acknowledgements The Barcoding Facility for Organisms and Tissues of Policy Concern (BopCo) is supported by the Belgian Science Policy Office (Belspo) as part of the Belgian Federal in-kind contribution to the European Research Infrastructure Consortium LifeWatch. We thank the Capacities for Biodiversity and Sustainable Development (CEBioS) programme, funded by the Belgian Development Cooperation (DGD) for financial support to the Congolese researchers.

Author contributions TB, MDM, SG and EV contributed to the study conception and design. Material preparation, data collection and analysis were performed by FG, SG, PM, CN, SN, MP and SVDH. The first draft of the manuscript was written by SG and all authors commented on previous versions of the manuscript. All authors read and approved the final manuscript.

Funding Not applicable.

Data availability The sequences generated during the current study are available in the GenBank repository.

Code availability Not applicable.

\section{Compliance with ethical standards}

Conflict of interest The authors declare that they have no conflict of interest.

Open Access This article is licensed under a Creative Commons Attribution 4.0 International License, which permits use, sharing, adaptation, distribution and reproduction in any medium or format, as long as you give appropriate credit to the original author(s) and the source, provide a link to the Creative Commons licence, and indicate if changes were made. The images or other third party material in this article are included in the article's Creative Commons licence, unless indicated otherwise in a credit line to the material. If material is not included in the article's Creative Commons licence and your intended use is not permitted by statutory regulation or exceeds the permitted use, you will need to obtain permission directly from the copyright holder. To view a copy of this licence, visit http://creativecommons.org/licenses/by/4.0/. 


\section{References}

Bair-Brake H, Bell T, Higgins A et al (2014) Is that a rodent in your luggage? A mixed method approach to describe bushmeat importation into the United States. Zoonoses Public Health 61:97-104

Bitanyi S, Bjørnstad G, Nesje M et al (2011) Molecular identification versus local people's information for accurate estimates of bushmeat utilization from the Serengeti ecosystem, Tanzania. Afr J Biotechnol 11:243-252

Boratto R, Gore ML (2018) The bushmeat supply chain in Pointe Noire, Republic of the Congo: a conservation criminology analysis. Report prepared for the Wildlife Conservation Society. Michigan State University, Michigan

Brown S (2006) The West Develops a Taste for Bushmeat. New Sci 2559:8. https://www.newscientist.com/ article/dn9503-the-west-develops-a-taste-forbushmeat/

Brown T, Marks SA (2008) Livelihoods, hunting and the game meat trade in Northern Zambia. In: Davies G, Brown D (eds) Bushmeat and livelihoods: wildlife management and poverty reduction. Blackwell Publishing Ltd, Oxford, pp 92-105

Cawthorn D-M, Hoffman LC (2015) The bushmeat and food security nexus: a global account of the contributions, conundrums and ethical collisions. Food Res Int 76:906-925

Chaber A-L, Allebone-Webb S, Lignereux Y et al (2010) The scale of illegal meat importation from Africa to Europe via Paris. Conserv Lett 3:317-321

D'Amato ME, Alechine E, Cloete KW et al (2013) Where is the game? Wild meat products authentication in South Africa: a case study. Investig Genet. https://doi.org/10.1186/2041-2223-4-6

Dawson S (2018) Bushmeat. In: Costa R, Pittia P (eds) Food ethics education. Integrating food science and engineering knowledge into the food chain, vol 13. Springer International Publishing, Cham, pp 209-220

Ducroz JF, Volobouev V, Granjon L (2001) An Assessment of the systematics of arvicanthine rodents using mitochondrial DNA sequences: evolutionary and biogeographical implications. J Mamm Evol 8:173-206

European Commission (2019) Commission Delegated Regulation (EU) 2019/2122 of 10 October 2019 supplementing Regulation (EU) 2017/625 of the European Parliament and of the Council as regards certain categories of animals and goods exempted from official controls at border control pos. Off J Eur Union 321:45-63

Fa JE, Brown D (2009) Impacts of hunting on mammals in African tropical moist forests: a review and synthesis. Mamm Rev 39:231-264

Falk H, Dürr S, Hauser R et al (2013) Illegal import of bushmeat and other meat products into Switzerland on commercial passenger flights. Rev sci tech Off int Epiz 32:727-739

Folmer O, Black M, Hoeh W et al (1994) DNA primers for amplification of mitochondrial cytochrome c oxidase subunit I from diverse metazoan invertebrates. Mol Mar Biol Biotechnol 3:294-299

Galimberti A, Sandionigi A, Bruno A et al (2015) DNA barcoding in mammals: what's new and where next? Hystrix Ital J Mammal 26:13-24

Gaubert P, Njiokou F, Olayemi A et al (2015) Bushmeat genetics: setting up a reference framework for the DNA typing of African forest bushmeat. Mol Ecol Resour 15:633-651

Guicking D, Lawson R, Joger U, Wink M (2006) Evolution and phylogeny of the genus Natrix (Serpentes: Colubridae). Biol J Linn Soc 87:127-143

Ichikawa M, Hattori S, Yasuoka H (2016) Bushmeat crisis, forestry reforms and contemporary hunting among Central African forest hunters. In: Reyes-García V, Pyhälä A (eds) Hunter-gatherers in a changing world. Springer International Publishing, Cham, pp 59-75

Jansen W, Merkle M, Daun A et al (2016) The quantity and quality of illegally imported products of animal origin in personal consignments into the European Union seized at two German airports between 2010 and 2014. PLoS One. https://doi.org/10.1371/journal.pone.0150023

Katani R, Schilling MA, Lyimo B et al (2019) Microbial diversity in bushmeat samples recovered from the Serengeti ecosystem in Tanzania. Sci Rep 9:1-11. https://doi.org/10.1038/s41598-019-53969-7

Kurpiers LA, Schulte-Herbrüggen B, Ejotre I, Reeder DAM (2016) Bushmeat and emerging infectious diseases: lessons from Africa. In: Angelici F (ed) Problematic wildlife: a cross-disciplinary approach. Springer International Publishing, Cham, pp 507-551

Lindsey PA, Romañach SS, Matema S et al (2011) Dynamics and underlying causes of illegal bushmeat trade in Zimbabwe. Oryx 45:84-95

Marris E (2006) Bushmeat surveyed in Western cities. Nat News. https://doi.org/10.1038/news060626-10

Milius S (2005) Bushmeat on the menu-untangling the influences of hunger, wealth, and international commerce. Sci News 167:138-140 
Minhós T, Wallace E, Ferreira da Silva MJ et al (2013) DNA identification of primate bushmeat from urban markets in Guinea-Bissau and its implications for conservation. Biol Conserv 167:43-49

Nasi R, Brown D, Wilkie D et al (2008) Conservation and use of wildlife-based resources: the bushmeat crisis. Secretariat of the Convention on Biological Diversity, Montreal and Center for International Forestry Research (CIFOR), Bogor

Oger G (2011) Bushmeat black market thrives in Paris. The World from PRX, Boston, Massachusetts

Okiwelu SN, Ewurum N, Noutcha AE (2009) Wildlife harvesting and bushmeat trade in Rivers State, Nigeria: I species composition, seasonal abundance and cost. Sci Afr 8:1-8

Olayemi A, Oyeyiola A, Antunes A et al (2011) Contribution of DNA-typing to bushmeat surveys: assessment of a roadside market in south-western Nigeria. Wildl Res 38:696-716

Ripple WJ, Abernethy K, Betts MG et al (2016) Bushmeat hunting and extinction risk to the world's mammals. R Soc Open Sci. https://doi.org/10.1098/rsos.160498

Smith KM, Anthony SJ, Switzer WM et al (2012) Zoonotic viruses associated with illegally imported wildlife products. PLoS One. https://doi.org/10.1371/journal.pone.0029505

Swamy V, Pinedo-Vasquez M (2014) Bushmeat harvest in tropical forests: knowledge base, gaps and research priorities. Center for International Forestry Research (CIFOR), Bogor

Walz E, Wilson D, Stauffer JC et al (2017) Incentives for bushmeat consumption and importation among west African immigrants, Minnesota, USA. Emerg Infect Dis 23:2095-2097

Wilkie DS, Wieland M, Boulet $\mathrm{H}$ et al (2016) Eating and conserving bushmeat in Africa. Afr J Ecol $54: 402-414$

Wood KL, Tenger B, Morf NV, Kratzer A (2014) CITES-listed species at risk from the illegal trafficking of bushmeat; results of a 2012 study in Switzerland's International Airports. Unpublished report to CITES. Tengwood Organzation, Wallisellen

Publisher's Note Springer Nature remains neutral with regard to jurisdictional claims in published maps and institutional affiliations.

\section{Affiliations}

\section{Sophie Gombeer ${ }^{1}$ (D) - Casimir Nebesse ${ }^{2}$ Prescott Musaba ${ }^{2}$ - Steve Ngoy $^{2}$. Marc Peeters ${ }^{3} \cdot$ Ann Vanderheyden $^{1} \cdot$ Kenny Meganck ${ }^{4} \cdot$ Nathalie Smitz $^{4}$ • Frank Geers $^{5}$ - Sarah Van Den Heuvel ${ }^{6} \cdot$ Thierry Backeljau $^{1,7} \cdot$ Marc De Meyer $^{4}$. Erik Verheyen 7,8}

1 BopCo, Royal Belgian Institute of Natural Sciences, 1000 Brussels, Belgium

2 University of Kisangani, B.P. 2012, Kisangani, Democratic Republic of the Congo

3 National Focal Point to the Convention on Biological Diversity, Royal Belgian Institute of Natural Sciences, 1000 Brussels, Belgium

4 BopCo, Royal Museum for Central Africa, 3080 Tervuren, Belgium

5 MaResCon Consulting, 9030 Mariakerke, Belgium

6 Brussels Airport Company - Sustainable Development, 1930 Zaventem, Belgium

7 Evolutionary Ecology Group, University of Antwerp, 2610 Antwerp, Belgium

8 OD Taxonomy \& Phylogeny, Royal Belgian Institute of Natural Sciences, 1000 Brussels, Belgium 